\title{
CONGENITAL CUTANEOUS KAPOSIFORM HEMANGIOENDOTHELIOMA IN A NEWBORN CALF
}

\author{
Erkmen Tuğrul Epikmen¹, Ahmet Aydogan², Hamdi Avci', Sümbül Serap Birincioğlu ${ }^{3}$ \\ ${ }^{1}$ Department of Pathology, Faculty of Veterinary Medicine, \\ University of Aydin Adnan Menderes, Aydin, Turkey \\ ${ }^{2}$ Department of Pathology, Faculty of Ceyhan Veterinary Medicine, \\ University of Çukurova, Adana, Turkey \\ ${ }^{3}$ Special A Pathology Laboratory, Izmir, Turkey
}

Received 23 December 2019; Received in revised form 24 March 2020; Accepted 30 March 2020

\begin{abstract}
A one-day-old female Holstein calf was presented with subcutaneous masses spread over the whole body. Macroscopically, the masses were firm in touch, greyish-white in colour, $0.5-2 \mathrm{~cm}$ in diameter range. Histopathological examination confirmed the cutaneous Kaposiform hemangioendothelioma (KHE). Microscopic examination of the tumor revealed sheets of spindled endothelial cells forming vascular slits. Immunohistochemically, the tumor cells and capillaries gave strongly positive reaction for CD31 while vimentin, alpha smooth muscle actin and cytokeratin AE1/AE3 were negative. In this case, macroscopical, detailed histhopathological and immunohistochemical findings of congenital KHE reported firstly in a newborn calf.
\end{abstract}

Key words: kaposiform hemangioendothelioma, pathology, immunohistochemistry, new-born calf

\section{INTRODUCTION}

Kaposiform hemangioendothelioma (KHE) is a rare, locally aggressive, low-grade, malignant vascular neoplasm of the skin, deep soft tissue, and bone in human $(1,2)$. It is typically seen in childhood, with $45 \%$ of cases present within the first year of life, often occur at birth (3). This neoplasm shows significant resemblance to Kaposi's sarcoma (1). Multiple cutaneous KHE is extremely rare and was present during the birth of a human only in three cases $(4,5)$. In addition, few cases of Kaposi's sarcoma in middle-aged female dogs, KHE was found in a six-year-old Fischer's

Corresponding author: Dr. Ahmet Aydogan, $\mathrm{PhD}$

E-mail address: aaydogan79@gmail.com

Present address: Department of Pathology, Faculty of Ceyhan Veterinary

Medicine, University of Çukurova, Adana, Turkey

Phone: +905309263179

Copyright: (C) 2020 Aydogan A. This is an open-access article published under the terms of the Creative Commons Attribution License which permits unrestricted use, distribution, and reproduction in any medium, provided the original author and source are credited.

Competing Interests: The authors have declared that no competing interests exist.

Available Online First: 28 May 2020

Published on: 15 October 2020

https://doi.org/10.2478/macvetrev-2020-0018 lovebird (Agapornis fischeri) on the neck, and in a 10 -year-old dog on its limb $(6,7,8)$. We present here a new-born calf having cutaneous KHE and to the best of our knowledge, it is the first case of KHE in a new-born calf.

\section{MATERIAL AND METHODS}

A one-day-old, female, Holstein dead calf was presented to Pathology department of Faculty of Veterinary Medicine, Aydin Adnan Menderes University with subcutaneous nodular masses. Necropsy examination was performed. The masses were routinely fixed in $10 \%$ buffered formalin solution and processed routinely for light microscopy. Five $\mu \mathrm{m}$ thick sections were taken from paraffin embedded tissues and stained with hematoxylin and eosin (H\&E). Selected sections were stained using the routine streptavidinbiotin peroxidase method with primary antibody against CD31 (platelet-endothelial cellular adhesion molecule, PECAM-1) antibody (Rabbit monoclonal to CD31, Sigma-Aldrich, Clone RM 
247, 1/1000 dilution, San Francisco, Ca, USA), alpha smooth muscle actin (Mouse monoclonal to alpha smooth muscle actin, Abcam, ab-18147, 0.5-1 $\mu \mathrm{g} / \mathrm{ml}$, Cambridge, UK), Vimentin (Mouse monoclonal to Vimentin, Abcam, ab8069, 1/100 dilution, Cambridge, UK), Cytokeratin AE1/AE3 (Mouse monoclonal anti-human Cytokeratin, Dako, Clones AE1-AE3, 1/50 dilution, Glostrup, Denmark). The colour was visualized by DAB (3, 3'-diaminobenzidine chromogen, DAKO, Glostrup, Denmark) and counterstained with Harris' hematoxylin.

\section{RESULTS}

Gross examination of calf showed subcutaneous nodular masses spread over the whole body (Fig. 1A). Metastatic lesions were not found in peripheric and intrathoracic, as well as intra-abdominal lymph nodes and visceral organs (i.e. spleen, liver, lungs, and brain). The masses were firm in touch, greyish-white in colour,
$0.5-2 \mathrm{~cm}$ in diameter range (Fig. 1B). Some of these masses showed petechial or severe haemorrhages. The cut surfaces of the masses were homogeneous, greyish-white, reddish-white or dark red in colour according to whether there were haemorrhages (Fig. 1C and D).

At microscopical examination, tumour was showed diffuse distribution in the dermis and subcutis. The tumoral area were composed of sheets of spindled and round epithelioid endothelial cells intermixed with slit-like vascular lumens and extravasated red blood cells (Fig. 2A). The atypia of the spindle and round epithelioid endothelial cells was minimal and mitoses were not frequent ( 2 mitotic figures per 10 high-power fields). No metastases were seen in any organ. Immuno-histochemically, the tumour cells and capillaries gave strongly cytoplasmic positive reaction for CD31 (Fig. 2B) but they were negative for vimentin, alpha smooth muscle actin and cytokeratin AE1/AE3. Control sections revealed negative or weak immunostaining confirming the specificity of the primary antibodies.
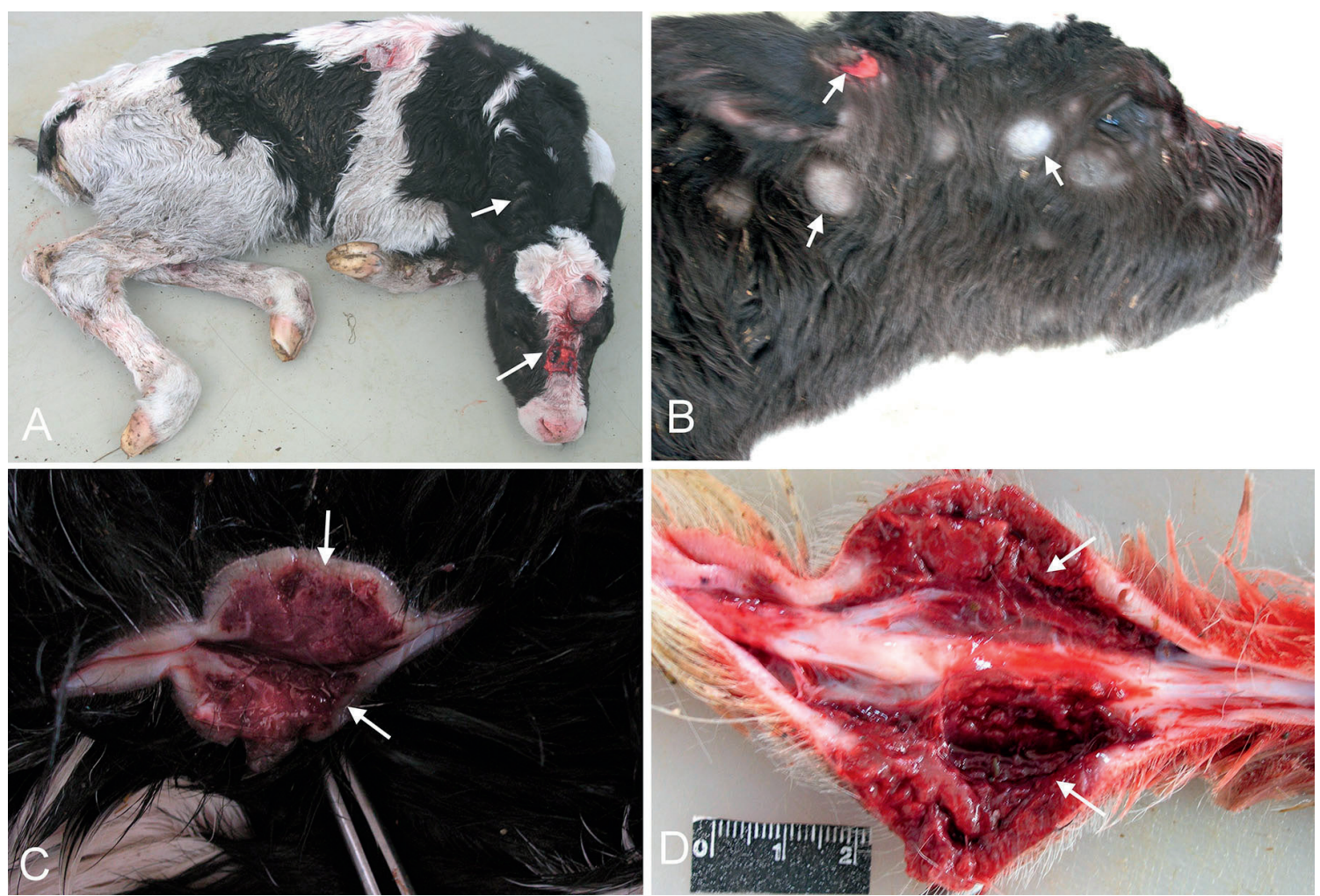

Figure 1. Cutaneous nodular masses spread over the whole body of the calf (arrows) (A). Greyishwhite tumour masses (arrows) (B). Cut surface of the haemorrhagic mass taken from shoulder (arrows) (C and D) 


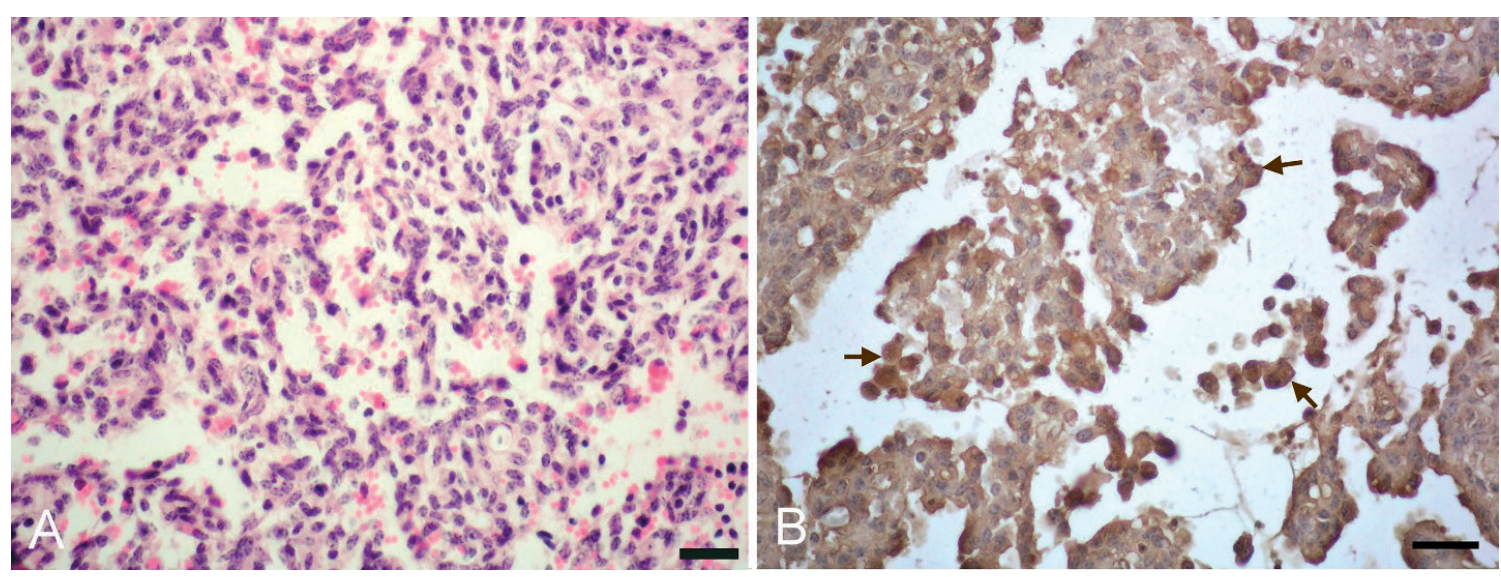

Figure 2. Histopathological section of kaposiform hemangioendothelioma, sheets of spindled and round epithelioid endothelial cells (H\&E., Bar-50 $\mu \mathrm{m})(\mathrm{A})$. Strong cytoplasmic staining of the tumour cells for CD31 (arrows). Streptavidin biotin method, Harris haematoxylin counterstain (Bar-30 $\mu \mathrm{m})(\mathrm{B})$.

\section{DISCUSSION}

Kaposiform hemangioendothelioma is an extremely rare and distinctive tumour of soft tissue that apparently occurs exclusively in children and oftenseenatbirth $(3,9)$. Innon-humananimalspecies, it has been previously reported from a Fischer's lovebird (Agapornis fischeri) and a dog $(6,7)$. To the author's knowledge, this is the first report that defines the detailed pathological findings of congenital KHE in a new-born Holstein calf. In accordance with human cases that were reported in children, this case was occurred in a new-born calf.

In the previous animal reports of KHE, macroscopically, the mass was located in the neck of the Fischer's lovebird while the other mass was located in the limb of the dog. In the dog, clustered red papules are seen on posterior limb. A subcutaneous mass with blood content on the neck is observed in the Fischer's lovebird $(6,7)$. However, in the present case, it has been seen that several firm nodular masses are spread over the whole body.

Microscopically, the tumour has area varieties from resembling a capillary hemangioma to solid areas. The solid areas show varieties from rounded nests of epithelioid endothelial cells to solid sheets of spindled endothelial cells with slit-like vascular lumens $(5,10)$. In a previous case, it has been reported that dermal nodules are composed of spindle cells forming vascular slits and this histologic appearance is similar to Kaposi's sarcoma (6). In this report, in accordance with previous reports, sheets of spindled and round epithelioid endothelial cells intermixed with slit-like vascular lumens were observed. In the previous reports, mitotic activity was seen as scant to occasional and nuclear polymorphism was observed as mild to moderate $(6,7,10)$. In this case, the atypia of the tumour cells was minimal and mitoses were not frequent.

In the different reports of KHE, immunohistochemistry is used for diagnosis $(5,6,7$, 11). CD31 is a $130-\mathrm{kd}$ trans membrane glycoprotein and has been previously reported as a reliable and specific immunohistochemical marker of endothelial differentiation in the different studies $(12,13)$. Previous KHE case reports described positive CD31 expressions in the tumour cells and capillaries (5, $6,7,11)$. In the present report, the tumour cells and capillaries have given strong reaction for CD31. This immunohistochemical finding was also supportive of KHE diagnosis. However, negative reaction was observed for vimentin, alpha smooth muscle actin and cytokeratin AE1/AE3 in the tumour cells. Accordingly, in a KHE case report, positive CD31 and CD34 expressions are observed while muscle specific actin is negative in the tumour cells (5). In another KHE case report, positive CD31 and vimentin expressions are noted in the tumour cells (7).

\section{CONCLUSION}

In this case report, a novel accidental case of congenital KHE was presented in a new-born calf. Further research on this category should enhance our understanding of oncogenic mechanisms. To the best of our knowledge, this unusual case is the first report of Kaposiform hemangioendothelioma in a new-born calf. 


\section{CONFLICT OF INTEREST}

The authors declared that they have no potential conflict of interest with respect to the authorship and/or publication of this article.

\section{AUTHORS' CONTRIBUTIONS}

ETE participated in necropsy, histopathology, immunohistochemistry, writing the article, adaptation to the journal; AA participated in writing the article, literature review and adaptation to the journal; HA performed necropsy, histopathology, literature review; SSB carried out control and supervision

\section{REFERENCES}

1. Zukerberg, L.R., Nickoloff, B.J., Weiss, S.W. (1993). Kaposiform hemangioendothelioma of infancy and childhood. An aggressive neoplasm associated with Kasabach-Merritt syndrome and lymphangiomatosis. Am J Surgic Pathol. 17(4): 321-328.

https://doi.org/10.1097/00000478-199304000-00001 PMid:8494101

2. Tsang, W.Y.W. (2002). Kaposiform hemangioendothelioma. In: Fletcher CDM, Unni KK, Mertens F. (Eds.), World Health Organization classification of tumors: pathology and genetics, tumors of soft tissue and bone (pp. 163-164), Lyon, France: IARC.

3. Lyons, L.L., North, P.E., Mac-Moune Lai, F., Stoler, M.H., Folpe, A.L., Weiss, S.W. (2004). Kaposiform hemangioendothelioma: a study of 33 cases emphasizing its pathologic, immunophenotypic, and biologic uniqueness from juvenile hemangioma. Am J Surgic Pathol. 28, 559-568.

https://doi.org/10.1097/00000478-200405000-00001 PMid:15105642

4. Enjolras, O., Wassef, M., Mazoyer, E., Frieden, I.J., Rieu, P.N., Drouet, L., et al. (1997). Infants with Kasebach-Merritt syndrome do not have "true hemangiomas". J Pediatr. 130(4): 631-640. https://doi.org/10.1016/S0022-3476(97)70249-X

5. Gianotti, R., Gelmetti, C., Alessi, E. (1999). Congenital cutaneous multifocal kaposiform hemangioendothelioma. Am. J. Dermatopathol. 21(6): 557.

https://doi.org/10.1097/00000372-199912000-00010

PMid:10608250
6. Vincek, V., Zaulyanov, L., Mirzabeigi, M. (2004). Kaposiform hemangioendothelioma: the first reported case in a nonhuman animal species. Vet Pathol. 41(6): 695-697.

https://doi.org/10.1354/vp.41-6-695 PMid:15557080

7. Giacomo, R., Livio, G., Sara, B., Maria Assunta, P., Patrizia, R., Timothy, R., Maria Luisa, C. (2016). Neck kaposiform haemangioendothelioma in a Fischer's lovebird (Agapornis fischeri). Res Vet Sci. 106, 112-115.

https://doi.org/10.1016/j.rvsc.2016.03.018

PMid:27234547

8. Goldschmidt, M.H., Hendrick, M.J. (2002). Tumors of the skin and soft tissues. In: Meuten DJ. (Ed.), Tumors in domestic animals (pp. 102-103). 4th Ed. Ames, USA: Iowa State Press.

9. Vin Christian, K., Mc Calmont, T.H., Frieden, I.J. (1997). Kaposiform hemangioendothelioma. An aggressive, locally invasive vascular tumor that can mimic hemangioma of infancy. Arch Dermatol. 133(12): 1573-1578.

https://doi.org/10.1001/archderm.133.12.1573

PMid:9420544

10. Debelenko, L.V., Perez-Atayde, A.R., Mulliken, J.B., Liang, M.G., Archibald, T.H., Kozakewich, H.P. (2005). D2-40 immunohistochemical analysis of pediatric vascular tumors reveals positivity in kaposiform hemangioendothelioma. Mod Pathol. 18, 1454-1460.

https://doi.org/10.1038/modpathol.3800444

PMid:15920541

11. Stratton, J.S., Billings, S.D. (2009). Vascular tumors of intermediate malignancy: a review and update. Dermatologica Sinica 27(3): 140-153.

12. Miettinen, M., Lindenmayer, A.E., Chaubal, A. (1994). Endothelial cell markers CD31, CD34, and BNH9 antibody to $\mathrm{H}$ - and Yantigens: evaluation of their specificity and sensitivity in the diagnosis of vascular tumors and comparison with von Willebrand factor. Modern Pathol. 7(1): 82-90.

13. De Young, B.R., Frierson, H.F., Micki, N., Smith, D., Swanson, P.E. (1998). CD31 Immunoreactivity in Carcinomas and Mesotheliomas. Am J Clin Pathol. 110(3): 374-377.

https://doi.org/10.1093/ajcp/110.3.374

PMid:9728613 